\title{
ДОСЛІДЖЕННЯ ПРИТАМАННИХ ДРУЖИНАМ ЗАГИБЛИХ ПРАВООХОРОНЦІВ КОПІНГ-СТРАТЕГІЙ ПОДОЛАННЯ ВТРАТИ ПРИ СИСТЕМНОМУ ПСИХОЛОГІЧНОМУ СУПРОВОДЖЕННІ
}

УДК: 152.3

\section{Рибик Лариса Анатолӥвна}

Ад’юнкт Національної академії внутрішніх справ, м. Київ(Україна)

\begin{abstract}
Анотація. Стаття містить результати емпіричного дослідження моделей копінгстратегій особистості в умовах психологічної травми через втрату близької людини у дружин правоохоронців, яки загинули під час виконання службових обов'язків. Розглядається діапазон основних моделей подолання екстремальних ситуацій та сприйняття конкретних стратегій 3 точки зору украӥнської ментальності та з урахуванням специфіки травми. Проаналізований вплив основних детермінуючих характеристик на вибір пріоритетних копінг-стратегій. Дослідницька модель передбачає два етапи діагностики - тест в перші місяиі після втрати, ретест через рік в двох групах - експериментальній та контрольній. В процесі роботи були отримані результати, якісвідчать про сприятливий вплив психологічного супроводження на адаптивне переживання втрати.
\end{abstract} особистості.

Ключові слова: вдови, копінг-стратегії, психологічна травма, адаптація

Постановка проблеми. Один $з$ етапів надання психологічної допомоги вдовам розкриття механізмів копінгу та подальша психокорекція спрямована на формування адаптивного стилю життєдіяльності.

Теорія подолання особистості важких життєвих ситуацій - копінг, має на увазі, що постійно змінюються когнітивні, емоційні і поведінкові спроби впоратися зі специфічними зовнішніми або внутрішніми вимогами, які оцінюються як напруга або перевищують мо- жливості людини впоратися 3 ними [21]. Особистісні ресурси при цьому є основою формування стратегій. Функціональна спрямованість поведінки, яку людина вибирає при переживанні екстремальних ситуацій, спрямована на усунення або зниження стресу, або на відновлення первісного стану [4].

Копінг-поведінка - це форма біхевіоральнаго відображення психологічної готовності, або неготовності, індивіда вирішувати життєві проблеми. При цьому людина використо- 
вує різні стратегії в процесі подолання важких життєвих ситуацій, іноді поєднуючи їх. Не існує моделей, які були б ефективні у всіх ситуаціях. Вибір прийомів - суб'єктивне рішення, засноване на індивідуально-психологічній особливості, життєвому досвіді, оцінці значущості події, що відбувається, та інших фактоpax [1]. Копінг-процес не є константою, так як взаємозв'язок суб'єкта з об'єктивною реальністю відбувається на різних рівнях і носить динамічний характер.

Традиційно копінг-стратегії, в першому приближенні, класифікують за трьома видами - проблемно-орієнтована, емоційноорієнтована і уникнення. Р. Лазарус і С. Фолкман ввели поняття «інструментальної» моделі поведінки подолання - рішення проблеми, яка викликає дистрес і «паліативної» - управління емоційними реакціями на цю проблему. Відразу хотілося б відзначити, що в ситуації втрати підхід дещо інший. По-перше - ніякими діями не можна вирішити проблему смерті близької людини. Будь-яка активність буде спрямована на заміщення значимого об'єкта. По-друге - робота горя складається в повному проживанні емоцій. Контроль, управління або придушення емоцій може привести до негативних ситуацій, загнані в підсвідомість вони проявляться через депресію або психосоматичні захворювання.

Ми будемо розглядати даний феномен в світлі адаптивної поведінки, спрямованої на адекватне сприйняття ситуації людиною. У цьому контексті копінг-поведінка поєднує пристосування до змінених умов життя шляхом активної адаптації, а також спроби вибудувати нову систему буття. При втраті близької людини поведінка зумовлена не тільки ситуацією і соціокультурним впливом, а й суб'єктивною інтерпретацією об'єктивної реальності, а також, що не менш важливо, наскільки значущим був загиблий чоловік.

Копінг-стратегії знижують психологічну напругу і тривожність, інтенсивність яких обумовлена особистісними характеристиками. Одна і та ж ситуація втрати викликає у різних жінок психологічне потрясіння різної інтенсивності і різне сприйняття психотравмуючої події. Це обумовлено темпераментом, характером і волею. Будь-який акт копінгової дії $\epsilon$ частиною стратегії, в свою чергу стратегії утворюють копінгові стилі поведінки. Вони характеризуються як функціональні і дисфункціональні, тобто ефективні і непродуктивні.

У нашому випадку ефективні копінгстратегії спрямовані на активну адаптацію i здорове заміщення. Голландські вчені Штробі і Шат в своїй моделі подвійного процесу поведінки подолання (The Dual Process Model of Coping) вказували на наявність безпосередніх реакцій у відповідь на ситуацію напруги і на процедуру регулювання процесу. Відповідно до цієї моделі особа, що пережила важку втрату близької людини, намагається впоратися 3 непоправною втратою, а також прагнути відновити внутрішню рівновагу, що існувала ра- 
ніше. При цьому реагування проявляється безпосередніми, прямими, автоматичними, негайними і спонтанними реакціями на травматичну ситуацію. У той час як регулювання процесу відображає як довільні, так і навмисні дії, спрямовані на актуалізацію фізіологічних реакцій, управління емоціями, поведінкою і усвідомленням як відгуку на психотравму.

Життєві стратегії, які допомагають пережити втрату, безпосередня робота горя, включає в себе безліч аспектів. На початковому етапі вона може трактуватися як першочергове завдання адаптації в ситуації втрати, здійснювана в режимі невідкладної імпульсивної і навіть, в якійсь мірі, не цілком усвідомленої допомоги. Це своєрідна «ефективна» система регуляції стресу, те, що ми називаємо прийняття ситуації [22].

Наступний етап, відновлення, орієнтований на подолання впливу вторинних стресорів, що розглядається в сучасній психології як вторинний ПТСР [13], які є наслідком перенесеної втрати, такими як зміна власної ідентичності, зміна соціальної ролі, прийняття додаткової відповідальності і оволодіння практичними навичками виконання обов'язків, які раніше виконував померлий. «Модель подвійного процесу опанування визначає адаптивний копінг як включення зворотно - поступального руху між подоланням шкоди і відновленням, яке існувало до впливу стресового стану, униканням проблеми і 11 вирішенням, минулим і майбутнім, між орієнтаціями на негатив- ну і позитивну переоцінку» [18]. У разі переживання втрати процеси реагування і регулювання не завжди послідовні, вони можуть бути паралельними і одночасними.

Емпіричні дослідження показали, що механізми захисту і механізми опанування настільки межують, що іноді їх важко розділити i ідентифікувати. В академічній психології найбільш поширеним є припущення, що психологічний захист - це відмова особи від вирішення проблеми шляхом конкретних дій заради збереження комфортного стану. Тоді як способи подолання характеризуються необхідністю проявити конструктивну активність, пройти через ситуацію і пережити травмуючу подію. «Можна сказати, що предметом психології подолання, як спеціальної області дослідження, є вивчення механізмів емоційної і раціональної регуляції людиною своєї поведінки 3 метою оптимальної взаємодії з життєвими обставинами або їх перетворення відповідно до своїх намірів» [10, с. 191].

Взаємодія особистості з різними життєвими ситуаціями забезпечується шляхом реалізації еволюційно-програмних стратегій 3 урахуванням властивого людині інстинкту подолання. Вибір копінг-стратегій визначається індивідуально-психологічними особливостями, а вираженість різних способів реагування безпосередньо залежить від ступеня самоактуалізації особистості. Внутрішні установки i набутий досвід є фундаментом для побудови як захисних, так і опановуючих моделей реа- 
гування на психотравматичну ситуацію. Іншими словами, при усвідомленому або неусвідомленому формуванні копінг-стратегій задіяні когнітивні, афективні і поведінкові рівні ієрархічної структури психіки.

Таким чином, копінг-стиль формується 3 психологічних утворень (інтелекту, характеру і т.д.), стійких патернів організації індивідуальної діяльності і, безпосередньо, простору побудови активності. Аналіз копінг-стратегій вдів передбачає наявність структури та принципів побудови. Однак потрібно враховувати, що «вся сукупність індивідуальних психологічних знань свідчить про неможливість існування спеціальних механізмів, що забезпечують кожен з видів людської діяльності. Швидше справедливо зворотнє: структурнофункціональна організація психіки інваріантна і не змінюється при реалізації будь-якого виду діяльності ...» [5, с. 54].

Аналіз класичних концепцій структури копінг-стратегій дозволяє виділити інформаційну складову - отримання, переробка та зберігання інформації; програмуючу - контроль i регулювання складних форм діяльності; а також ресурсність - комплекс ключових ресурсів, які керують усією ресурсною системою. Також слід враховувати, що поведінкова система формується під впливом стійких детермінант поведінки і комплексних способів їх peaлізації. «Інтегративні процеси, що відбуваються при побудові активності, виявляються в поведінці у вигляді складних функціональних комплексів - індивідуальних технологій та стратегій поведінки» [16, с. 81].

Копінг-стратегія вибирається відповідно до особливостей об'єктивної реальності, однак копінг-стиль формується з урахуванням інтеграції ситуації через призму індивідуальності, ускладнюючи, таким чином, стратегію поведінки. Прояв стилю, як динамічної структури, здійснюється під впливом різних чинників. Аналіз концепцій, представлених в роботах психологів (А.Р. Лурия 1973, А.В.Либин 1998,Э. К.Коплик 1992, Морозова Т. Ю. 2008, С. Фолкман и Р. Лазарус 1984, Моос и Шеффер, Перлин и Шулер), а також власні емпіричні дослідження дали можливість сформулювати основний перелік факторів, що впливають на свідомий чи несвідомий вибір копінгстратегії.

\section{Аналіз факторів вибору копінг-} стратегій.

Суб'єктивний: характер, темперамент, інтелектуальні особливості, рівень тривожності, стресостійкість, біологічний вік, фізичне здоров'я .

Об'єктивний: реальна ситуація; насиченість певною інформацією; соціальний фактор, який формується 3 соціального статусу суб'єкта, соціокультурного впливу і фактичного середовища проживання (місце проживання, умови проживання).

Ресурси: матеріальні; соціальні; особистісні.

Інтернальність / екстернальність. Втра- 
та близької людини несе за собою втрату соціальної ролі. Соціальні ролі дружини і вдови мають різний рівень відповідальності і зобов'язань. Наприклад: традиційно чоловік - годувальник і при загибелі чоловіка в законодавстві прописано, що сім'я втратила годувальника. Значить, жінка, крім своїх обов'язків, повинна взяти на себе і функції чоловіка теж, тобто, додаткову відповідальність.

Реалізація короткострокових планів i щоденних завдань.

Реалізація довгострокових планів.

Фактично копінг-стратегії $\epsilon$ формою прояву окремих операцій або комплексних дій під впливом основних детермінуючих характеристик і спрямованих на формування стійких механізмів реагування. Один 3 таких механізмів це адаптивність психіки.

Будь-яка активність спрямована на формування комфортного середовища існування і усунення розбіжностей між існуючою ситуацією і сприйняттям себе як частини середовища в ідеальному варіанті. Напруга середовища, яке не може бути оптимально сприйнятим за допомогою наявних формально-динамічних параметрів стає предметом активності. Це провокує активацію наявних моделей поведінки або створення нових механізмів реагування. У нашому випадку поняття адаптація використовується в широкому сенсі, як прийняття суб'єктом мінливих умов життєдіяльності внаслідок психотравмуючої події (втрати) i побудова своєї активності з урахуванням змін, що відбулися. Ще один тип адаптації спрямований на зміну середовища, а значить і зміну потреб, завдань, для вирішення яких формуються функціональні системи і механізми регуляції. Дані механізми утворюють «складні регулятивні і когнітивні поведінкові комплекси, які проявляються як стійкі характеристики індивідуальності або особистості» [16, с. 83]. Найбільш складними комплексами є стратегії поведінки, тобто копінг-стратегії.

При вирішенні адаптивних завдань виділяється два типи факторів, що визначають індивідуальні особливості побудови копінгстратегій, а саме індивідуальні та соціальні. Перший тип передбачає формування стійких детермінант, другий - ситуативних. Аналіз стійких формально-динамічних характеристик дозволить прогнозувати поведінку індивідуума, засновану на системах реагування.

Інтерпретація даних діагностики копінг-стратегій дозволяє створити теоретичні класифікації механізмів регуляції, які в свою чергу будуть використовуватися в практичній психології для корекції моделей поведінки.

Пропонуємо описання притаманних вдовам типів переживань 3 урахуванням розуміння конкретних стратегій в рамках нашої ментальності на прикладі моделей запропонованої методики визначення індивідуальних копінг-стратегії Е. Хейма.

Копінг-стратегії в когнітивної сфері.

Адаптивні копінг-стратегіï.

Проблемний аналіз -проблемне струк- 
турування ситуації, що передбачає виділення комплексу питань, їх типологій, характеристик і шляхів вирішення.

Проблема - це виняткове загострення питання, яке потребує вирішення. Досить часто проблемними людина вважає ті аспекти, які, на іï думку, вона не здатна подолати самотужки.

Одним із принципових моментів є погляд на проблему як на нормальне явище, яке $\epsilon$ частиною життя i обов'язково супроводжує розвиток особистості. Вихід $з$ життєвих криз, що суб'єктивно переживаються як психологічні проблеми, відкриває додаткові ресурси, підвищує самооцінку, розширяє горизонти подальшого розвитку людини.

Розв'язання в різних випадках -це подолання; відреагування, звільнення деструктивного впливу; трансформація проблеми. При цьому досить часто потребується прийняття або й зміни ціннісних орієнтацій стосовно проблеми. «Розв’язання - це така робота 3 проблемою, в результаті якої людина не лише долає свої труднощі, але й «переживає» їх (використовуючи термін Ф. Ю. Василюка), збагачує свій досвід, гармонізує власне життя, тобто піднімається на новий рівень світосприймання» [6].

Отже проблемний аналіз дає можливість усвідомити певну інформацію, яка раніше не усвідомлювалася або витіснялася, зрозуміти свій психологічний стан і головне, намітити шляхи подолання кризи [6].
Установка власної цінності - кожна людина унікальна. Потрібно дати собі право бути собою і якщо на даний момент людина не може впоратися з труднощами, це не означає повне фіаско, з часом, адаптуючись до ситуації, що склалася, можна буде вирішити всі завдання, і навіть складніші, ніж $є$ на даний момент.

Як тільки людина приймає цю точку зору, всі питання 3 самооцінкою зникають. Однак, причини самооцінки закладені в несвідомих установках і можливо деякі будуть формувати нове самосприйняття. Основне завдання - перестати себе порівнювати з іншими, у кожного своя доля. Наступне завдання визнання своєї безумовної цінності, що не залежить ні від об'єктивних чинників, ні від суб'єктивних.

Установка власної цінності починається з чесності у ставленні до себе.

Збереження самопанування (самовладання) - це здатність діяти виважено і розумно в складних життєвих обставинах.

Самовладання включає в себе не тільки витримку, а й терпеливість, наполегливість, саморегуляцію і самоконтроль емоційних станів, які ведуть до стабільності ефективності діяльності.

Самовладання - це також здатність тверезо міркувати в моменти емоційного піку напруги, проте ця здатність індивідуальна і залежить від нейрофізіологічних і біохімічних реакцій організму, а також від соціокультурних 
установок. Внаслідок цього спостерігається абсолютно різна реакція в схожих ситуаціях.

Ми не можемо погодитися 3 думкою, що це абсолютно адаптивна копінг-стратегія, так як контроль емоційного стану може привести до придушення емоцій, виснаження нервової системи і як наслідок - психосоматичних захворювань. Ще раз наголошуємо на тому, що в роботі горя головне - відкрите проживання емоцій.

\section{Неадаптивні копинг-стратегії.}

Ігнорування- захисний механізм психіки, що полягає в несвідомому контролі джерела неприємного впливу, його наявності, характеру загрози, а також в обмеженні кількості такої інформації або іiї спотвореному сприйнятті.

Ігнорування - один 3 найпоширеніших способів психологічного захисту.

Завдяки ігноруванню, як техніці захисної реакції на наявність тієї чи іншої проблеми, людина умовно створює альтернативну реальність, в якій відсутні деякі інформаційні блоки.

Розглянемо деякі типи ігнорування:

- ігнорування факту того, що відбувається. Людина відмовляється сприймати об'єктивну реальність. До цього типу ігнорування ми можемо віднести неприйняття факту загибелі;

- ігнорування факту проблеми. В даному випадку мається на увазі прийняття того, що відбувається, але відмова визнати, що реа- льність представляє яку-небудь проблему. До цього типу ігнорування ми можемо віднести відмову сприймати свій психологічний стан як проблемний.

- ігнорування можливостей. Людина бачить ситуацію, визнає проблему, однак ігнорує існування можливостей іiі вирішення. В даному контексті мова йде про ігнорування будь-яких варіантів регулювання процесу переживання психотравмуючої події.

У свою чергу ігнорування можливостей можна розділити на кілька видів: ігнорування наявності можливостей; ігнорування значущості можливостей, точніше - сумнів в їх ефективності; ігнорування варіанту зміни можливостей; ігнорування особистих здібностей, яке базується на невпевненості в своїх силах i страху скористатися наданими можливостями.

Однак ми не можемо заперечувати наявність раціонального ігнорування, коли апатична поведінка пов'язана 3 відсутністю будьякої вигоди, відмовою від участі в певній дії, або відсутністю енергії на активність. У подібних випадках психологія ігнорування трактується як захист (пасивність захищає від витрати енергіï).

Смиренність - означає сповнення покори [15]. Усвідомлення та приборкання своїх негативних почуттів, прагнень. Розуміння смирення як цінності, як психологічної можливості впоратися 3 не завжди бажаними життєвими обставинами, стало частиною внутрішнього життя багатьох людей. 
Але іноді смиренність, яка по великому рахунку може бути проявом великої сили волі - прийняти долю, коли змінити нічого не можливо, ця сама смиренність може стати пасткою - псевдо смиренність.

Згідно з умовами тесту ця стратегія $є$ неадаптивною, але у випадку втрати - це адекватна реакція. Тому в контексті нашого дослідження адаптивність даної копінг-стратегії питання дискусійне.

Дисимуляція - поведінка, пов'язана 3 установкою на приховування, затушовування ситуації, переживань, почуттів або окремих їх проявів. Може мотивуватися і усвідомленими цілями - наприклад, небажанням показувати справжні переживання, - і несвідомими, в тому числі пов'язаними з компенсаторними формами особистісного реагування.

Вдаватися до диссимуляції- це значить робити вигляд, що ви не маєте того, що у вас $\epsilon$ насправді. Таким чином, диссимуляція «залишає недоторканим принцип реальності: різниця завжди ясна, вона лише замаскована» [3].

Роздубленість - це інтелектуальний стан, що характеризується втратою логічного зв'язку між здійснюваними або планованими діями. Порушується сприйняття ситуації, іiі аналіз і оцінка, внаслідок чого ускладнюється прийняття розумних рішень. Тому розгубленість характеризується недоцільними діями або повною бездіяльністю. Вона може супроводжувати паніку, але сама по собі не є пере- живанням небезпеки, хоча може бути іiі наслідком [8, с.154].

Неструктуровані ситуації припускають самостійність в ухваленні рішення, прийняття на себе відповідальності і вибір можливих ініціатив. При розгубленості людина перебуває в стані деякого ступору.

Розгубленість - не базова і не вроджена емоція, це скоріше вивчений стан. Серед інших його сенс і вигода - зняття з себе відповідальності.

Розгубленість не тривалий стан. Однак у людей, що переживають втрату близьких, іноді виникає внутрішній конфлікт між реальними емоціями і знанням, що вони повинні відчувати в даній ситуації. В такому випадку розгубленість може бути тривалою і стати причиною прихованої депресії.

\section{Відносно адаптивні копінг-стратегії.}

Вidносність -загальний принцип, згідно $з$ яким будь-яке явище має значення тільки щодо його зв'язку і відносин з якимось іншим. Цей принцип в повсякденному житті звучить «все пізнається в порівнянні».

Теорія відносності стверджує, що не існує нічого або майже нічого абсолютного.

Ключовий аспект даної копінг-стратегії полягає в порівнянні значимості втрати з тим, що людина має, наприклад діти, або з варіантом більш важкого розвитку події, або в порівнянні особистих переживань 3 переживаннями інших людей.

Додача сенсу - дає можливість людині 
розібратися не тільки в ситуації, а й визначити своє місце в житті і відповідно до подій, що відбуваються, розібратися в самому собі і визначити напрямок подальшого руху. Сенс виступає як життєвий орієнтир в психічній діяльності людини.

При виборі будь-якої копінг-стратегії вирішальну роль відіграє індивідуальна інтерпретація ситуації, а не образ об'єктивної реальності. Саме особистісний сенс відображає суттєві зв'язки і відносини, що дозволяє скласти прогноз майбутнього стану суб'єктнооб'єктної системи.

Додача сенсу можлива при наявності двох компонентів - логічності та корисності. Ці якості сенсу дозволяють «людській свідомості утримувати мінливу дійсність» [17, с. 5].

Сенс може стати «опорою буття людини, перетворюючи хиткість світу в логічно струнку будівлю доцільних зв'язків і відносин» [7].

Реліzійність - ступінь впливу релігії на свідомість і поведінку окремих індивідів.

Релігійні вчення впливають на переконання, ступінь моральної відповідальності і поведінку особистості під впливом фактору кризової ситуації, зіставляючи свободу волі і суб'єктність [20].

Звичайно ж релігійність - це один 3 аспектів духовності. Духовність ми розуміємо як принцип саморозвитку особистості в контексті загальнолюдських цінностей. У той час як релігійність можливо розглядати і як інтер- претацію особистісних смислів через призму релігійних концепцій, і як форму соціальної ідентичності, тобто приналежність до групи

Копінг-стратегії, що застосовуються жінкамив емоційній сфері.

Адаптивні копінг-стратегії.

Протест - рішучезапереченнячогонебудь, категорична заява про незгоду з кимось про небажаністьчого-небудь [14,c. 313].

Він можна проявлятись у вигляді відмови - пасивний протест і опозиції - активний протест.

1. Відмова - це форма захисної поведінки, в основі якої лежить неможливість задоволення базисних потреб у безпеці і захищеності. Пасивний протест включає підсвідомі захисні механізми ізоляції і заперечення. Реакція пасивного протесту проявляється у відстороненні від спілкування навіть з близькими людьми, відмову від їжі, усамітнення.

Опозиція. Психологічна стабільність особистості в величезній мірі залежить від впевненості в тому, що ніщо не зможе порушити відносин любові і прихильності. Коли ця впевненість підривається - виникає опозиція.

Onmuмізм (від лат. optimus - найкращий) - відображає позитивну ціннісну сторону світосприйняття; установки на прийняття спостережуваних явищ і взаємодія з ними засновані на можливості торжества добра.

Оптимізм безпосередньо пов'язаний 3 таким явищем як почуття життя, на яке впли- 
ває страх смерті [11]. Також оптимізм розглядається як частина суб'єктивного благополуччя, впливає на фізичне і психічне здоров'я [2].

Основну роль у феномені оптимізму грає активність, «як ознака соціально визнаної цілеспрямованої поведінки, результатом якої стають соціально корисні зміни» [12, с.11].

\section{Неадаптивні копінг-стратегії.}

Придушення емоцій - це психічний процес, який блокує прояв емоцій. Однак це тільки ситуативне рішення з приводу зовнішнього прояву емоцій.

Систематичне придушення породжується рядом причин:

- установки, спрямовані на переживання замість конструктивного рішення;

• негативізм;

- соціокультурні стереотипи щодо прояву емоцій.

Невиявлені глибинні почуття - це придушення переживань, що призводить до більш негативних наслідків у вигляді депресії і психосоматичних розладів.

Покірність - акт поступки іншим. Аналітики схильні відносити покірну поведінку до рубрик пасивність і мазохізм.

Покірність проявляється, коли людина не має можливості контролювати ситуацію. У стані психологічної пригніченості або депресії людина стає пасивною і вважає, що всі зусилля марні. Спостерігається «параліч» волі, пасивна смиренність і апатія, що в свою чергу блокує систему внутрішнього опору зовніш- нім факторам і прагнення зменшити залежність від обставин.

Цей стан класифікується як вивчена безпорадність і часто призводить до примітивізації життя.

Самозвинувачення - це приписування (атрибуція) до причин негативних подій власних дій. Також це схильність перебільшувати значимість своїх вчинків або приписування собі поганих вчинків, скоєних іншими людьми.

Процес самозвинувачення включає в себе визнання власних помилок, тому не є однозначно неадаптивною копінг-стратегією.

Однак найчастіше - це відсутність аналізу причинно-наслідкових зв'язків.

Іноді зустрічається демонстративне самозвинувачення, в разі маніпуляції або пошуку соціальної підтримки.

Агресивність - властивість особистості, яка проявляється в готовності до агресивної поведінки.

У агресивних суб'єктів сильно виражені конфліктні властивості, що призводить до утруднення в комунікації і вибудовуванні соціальних зв'язків.

Агресивність має зовнішній вектор руху і виражається у відношенні з оточуючими людьми і внутрішній вектор, спрямований на саморуйнування, тобто пов'язаний з вродженим прагненням до смерті.

\section{Відносно адаптивні копінг-стратегії}

Емоційна розрядка - (abreaction) зві- 
льнення від сильної емоційної реакції, пов'язаної з появою в свідомості пригнічених думок і спогадів.

Емоційна розрядка необхідна як свого роду перезавантаження організму для більш ефективної роботи всіх психосоматичних систем.

Якщо зняття емоційної напруги досягається за рахунок програвання ситуацій, що призвели до негативного емоційного переживання, відбувається в особливо організованих умовах, то відбувається не тільки звільнення, але усвідомлення індивідуальної значущості почуттів і емоцій.

Пасивна кооперація - поведінка, яка спрямована або на зняття напруги, пов'язаної 3 проблемами, емоційним реагуванням, або на передачу відповідальності за вирішення труднощів іншим особам.

Коли індивідуальна діяльність не призводить до бажаних результатів з'являється потреба в кооперації. Однак при пасивнії кооперації процес діяльності поділяється не пропорційно між учасниками, а результат в ідеальному варіанті задовольняє потреби кожного.

Копінг-стратегіï, що застосовуються жінками в поведінкової сфері.

Адаптивні копінг-стратегії.

Cniвnраця - позитивна взаємодія, в якій цілі і інтереси учасників збігаються або досягнення цілей одних учасників можливо тільки через забезпечення інтересів і прагнень інших учасників [9, с. 106]
Здатність до співпраці - властивість особистості, що є умовою успішної взаємодії суб'єктів в соціальному середовищі. Інтерес до інших людей і прагнення до співпраці - фундамент психічного здоров'я людини. Формування умінь розв'язувати життєві проблеми через співпрацю призводить до зменшення нервової напруги при зіткненні з екзогенними факторами.

Звернення - один 3 методів еффективного патерну поведінки розв'язання кризової ситуації.

Розрізняють два види допомоги, яку можуть надавати люди: автономна допомога, що сприяє навчанню і розумінню; вигідна допомога, що демонструє бажання перекласти виконання конкретних завдань на когонебудь.

Мотивацією до звернення $є$ когнітивні стадії готовності до зміни.

Серед внутрішніх перешкод, що заважають зверненню по допомогу, це, можливо, надмірна гордість, сором при визнанні своєї некомпетентності у вирішенні проблем і підвищена тривожність.

Альтруїзм -це принцип моральної поведінки людини, що має на увазі безкорисливість в діях, спрямованих на задоволення потреб оточуючих людей, з обмеженням власних інтересів і вигід.

Основні відмінні риси притаманні альтруїстичній поведінці: відсутність особистої вигоди в діях, прийняття на себе персональної 
відповідальності за наслідки цієї діяльності, пріоритетність інтересів інших людей, свобода вибору, продиктована внутрішнім альтруїстичним спонуканням, задоволення від реалізації свого потенціалу.

Прихильники соціальної теорії альтруїзму виділяють три основних компоненти:

- еволюиійний, якбіологічна програма живих істот, що сприяє збереженню генотипу;

- соиіальний взаємообмін, який трактується як глибинний прояв егоїзму, в зв'язку $з$ тим, що будь-яка дія свідомо і несвідомо розміряється 3 наявністю ресурсів (енергетичних, інформаційних, фізичних, матеріальних), витраченими зусиллями і отриманими бонусами;

- сочіальна норма, при якій надання допомоги - природна необхідність людини, яка визначає взаємодію індивіда в групі.

Відзначимо, що в період проведення ATO в Україні активно проявляється альтруїстичне поводження серед жінок.

\section{Неадаптивні копінг-стратегії.}

Активне уникнення - поведінкова реакція, спрямована на припинення травмуючої стимуляції або запобігання іï̈ настання.

Комбінація негативних суб'єктивних переживань, що мають в своїй основі страх, мотивує даний стиль поведінки. Таким чином, людина намагається зберегти стабільність свого внутрішнього емоційного стану за рахунок активних зовнішніх дій.

Використовуючи індивідуальний досвід, уникаючи будь-яких переживань, людина створює індивідуальну схему аперцепції і формує різні патерни по відношенню до світу.

Bidcmyn - механізм звільнення особистості від травмуючих негативних переживань шляхом відмови від діяльності.

Вихід з поля діяльності, як реакція на фруструючу подію, супроводжується зазвичай відмовою від активності, що може проявлятися в різних формах, наприклад, зниження (або відмову) від комунікацій, акумулювання поведінки, що сприяє символічному нівелюванню попередньої дії, що зазвичай супроводжується підвищеною тривожністю і іноді прихованою агресивністю.

\section{Відносно адаптивні копінг-стратегії}

Компенсація -відновлення порушеної рівноваги психічних і психофізіологічних процесів шляхом створення протилежноспрямованої реакції або імпульсу.

Компенсаторні якості (навички) є основними факторами формування особистості, яка намагається усвідомленим шляхом самостійно впоратися з важкою ситуацією.

Також компенсація розглядається як принцип психічної саморегуляції і взаємного урівноваження свідомих і несвідомих тенденцій в автономній психічній системі 3 подальшою реалізацією в поведінкових патернах.

Відволікання - зміна об'єкта спрямування енергії.

В даному випадку на допомогу приходить величезна мотиваційна сила емоції інтересу. Попередні дослідження показують, що 
емоція інтересу, завдяки силі, що фокусує, може притупити відчуття болю, хоча різні люди володіють різною здатністю до аналізу інтересу, до відволікання уваги від джерела неприємної стимуляції[19].

Будь-які способи відволікання - фізичні, психічні, емоційні і соціальні - не можуть усунути причину страждання, але в роботі горя допомагають перенести і подолати печаль. Відволікання сприяє усуненню і полегшенню емоцій, що пригнічують.

Конструктивна активність- форма взаємодії людини з соціальним середовищем, в якій акцентується змістовний аспект.

Емоційний стан впливає на активність людини, яка, в свою чергу, є важливим фактором ефективності адаптаційного процесу.

Конструктивна активність відображає розвиток особистості, через суб'єктивне перетворення і особистого і соціального досвіду на власні цінності, установки, орієнтації з метою побудови певної стратегії діяльності.

Матеріал і методика дослідження. Відповідно до завдань роботи, було здійснено дослідження при загальній вибірці, що складається 366 осіб. Жінки, чоловіки яких загинули під час виконання службових обов'язків пройшли анкетування.

Для участі в дослідженні було відібрано 32 особи, які пройшли програму психологічного супроводження (ЕГ) і 34 особи склали контрольну групу (КГ). Умовою відбору був термін після втрати - не більш ніж 3 місяці.
Як інструмент діагностики використовувалася методика визначення індивідуальних копінг-стратегіï Е. Heim (Method for Determination of Individual Coping-Stratagies, MDICS). (1988) в адаптації НІПНІ ім. В. М. Бехтерева (1998) під керівництвом д.м.н. професора Л. І. Вассермана. Ця методика дозволяє досліджувати 26 варіантів ситуаційно-специфічних копінг-стратегій на трьох рівнях психічної активності - когнітивної, емоційної і поведінкової.

Статистична обробка отриманих даних виконувалася 3 допомогою програми SPSSStatistics 23 ( «Statistical Package for the Social Sciences» - «статистичний пакет для соціальних наук»).

Для визначення величини приросту показників від першого тестування до другого проводилося обчислення та порівняння по tкритерію Ст'юдента.

Тест-ретест проводили з інтервалом 12 місяців і зіставляли результат за допомогою порівняння двох вибірок.

По тесту були отримані результати, які наведені в таблиці 1.

Результати дослідження. Аналіз відповідей показав явно виражений неадаптивний стиль подолання на першому етапі тестування у двох груп, до впровадження програми психологічного супроводження. Показники по всім критеріям майже ідентичні між двома групами при першому тестуванні (рисунок 1). Показники адаптивних стратегій складають 
Копінг - стратегії застосовувані жінками після втрати

\begin{tabular}{|c|c|c|c|c|c|c|c|c|c|}
\hline Група & $\kappa / \mathrm{a}$ & $\mathrm{K} / \mathrm{H}$ & К/B & $\mathrm{e} / \mathrm{a}$ & $\mathrm{e} / \mathrm{H}$ & е/B & $\Pi / \mathrm{a}$ & $\Pi / \mathrm{H}$ & $\Pi / \mathrm{B}$ \\
\hline $\mathrm{E} \Gamma / \mathrm{I}$ & 5 & 16 & 11 & 4 & 19 & 9 & 6 & 16 & 10 \\
\hline $\mathrm{K} \Gamma / \mathrm{I}$ & 6 & 17 & 11 & 3 & 22 & 9 & 6 & 16 & 12 \\
\hline $\mathrm{E} \Gamma / \mathrm{II}$ & 14 & 6 & 12 & 10 & 10 & 12 & 17 & 5 & 10 \\
\hline $\mathrm{K} \Gamma / \mathrm{II}$ & 8 & 12 & 14 & 4 & 19 & 11 & 10 & 12 & 12 \\
\hline $\begin{array}{l}\mathrm{E} \Gamma / \mathrm{I} \\
\%\end{array}$ & 15,6 & 50 & 34,4 & 12,5 & 59,4 & 28,1 & 18,75 & 50 & 31,25 \\
\hline $\begin{array}{l}\mathrm{K} \Gamma / \mathrm{I} \\
\%\end{array}$ & 17,65 & 50 & 32,35 & 8,8 & 64,7 & 26,5 & 17,7 & 47 & 35,3 \\
\hline $\begin{array}{l}\mathrm{E} \Gamma / \mathrm{II} \\
\%\end{array}$ & 43,75 & 18,75 & 37,5 & 31,25 & 31,25 & 37,5 & 53,1 & 15,65 & 31,25 \\
\hline $\begin{array}{l}\mathrm{K} \Gamma / \mathrm{II} \\
\% \\
\end{array}$ & 23,5 & 35,3 & 41,2 & 11,8 & 55,9 & 32,3 & 29,4 & 35,3 & 35,3 \\
\hline
\end{tabular}

від $8 \%$ до $18 \%$, в той час як неадаптивні близько 50\%, відносно адаптивні близько $30 \%$.

При повторному тестуванні показники двох груп значно відрізняються (Рисунок 2). При аналізі когнітивних копінг-стратегій можна відзначити, що в ЕГ показники не адаптивних стратегій зменшились з 50\% до 18,75 , а в

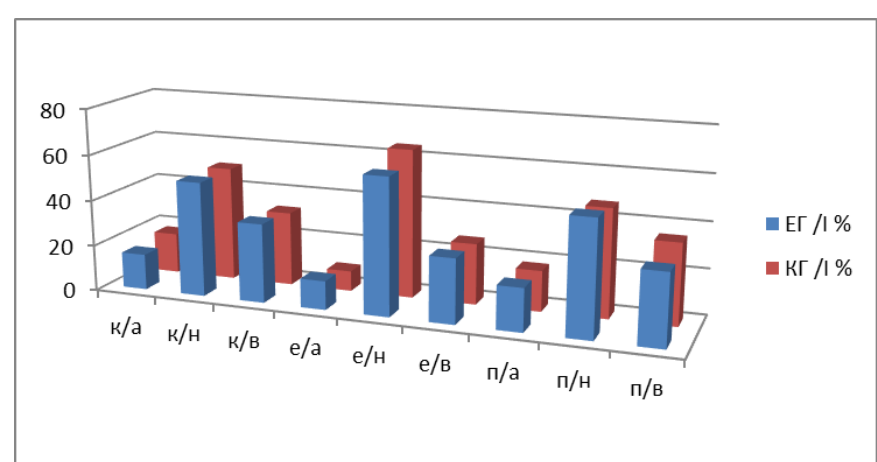

Рис. 1. Показники первинного тестування копінг - стратегій

КГ з 50\% до 35,3\%. Зокрема менше зустрічається «розгубленість» та ігнорування. Показники застосування відносно адаптивних стратегії, а саме «релегійність» і «надання сенсу», в обох групах збільшились. В ЕГ 3 34,4\% до $37,5 \%$, в КГ з 32,35\% до 41,2\%. Рівень вибору адаптивних стратегій підвищився в ЕК 3 $15,6 \%$ до $43,75 \%$ та 317,65 до $23,5 \%$ в КГ, зокрема слід відмітити пріоритетний вибір стратегії «збереження самоволодіння».

Аналізуючи емоційні стратегії, слід зазначити високий рівень не адаптивних форм, а саме при первинному тестуванні в ЕГ 59,4\% і в КГ 64,7\% та при повторному тестуванні $31,25 \%$ в ЕК і 55,9\% в КГ. Слід зазначити зменшення «самозвинувачення» в обох групах, але це природно при роботі з втратою. Також менше застосовувалась стратегія «придушення емоцій»в ЕГ.

Серед поведінкових стратегій подолання від самого початку спостерігався найвищій рівень адаптивних стратегій, порівняно $з$ когнітивними та емоційними. Так в ЕГ при першому тестуванні вони складали $18,75 \%$, а в 


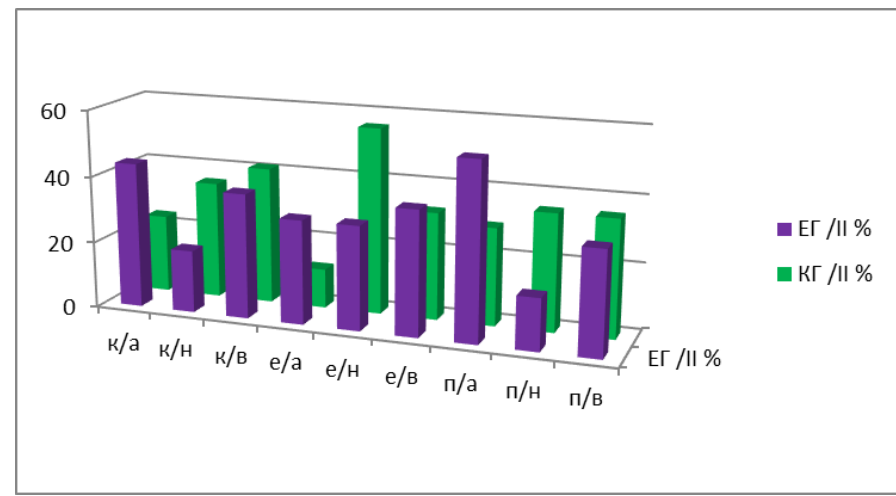

дорівнює 2,426, що дає підстави зробити висновок про більший рівень вираженості показників експерементальної групи.

Параметричний критерій дозволяє перевірити гіпотезу про позитивний вплив психологічного супроводження на адаптивність особистості. середнє значення двох сукупнос-

Рис.2 Показники другого тестування копінг- тей першого i другого тестування в ЕГ по стратегій

КГ - 17,7\%, а при повторному тестуванні в ЕГ складали $53,1 \%$, а в КГ - 29,4\%. Найчастіше в ЕГ використовується «звернення» та «співробітництво», а в КГ - «альтруїзм». Відносно адаптивні стратегії зовсім не змінилися, в ЕГ вони складають $31,25 \%$, а в КГ - 35,3\%. Але при першому тестуванні використовувались стратегії «відволікання» і «компенсація», а при повторному в обох групах переважала стратегія «конструктивна активність». Стосовно неадаптивних варіантів подолання в ЕГ показники знизились з 50\% до 15,65\%, в КГ від $47 \%$ до $35,3 \%$, а саме використання «активного уникнення». Це спостереження дає підстави зробити висновок, що жінки які вирішили самостійно справлятися 3 втратою, насамперед уникають стикатися 3 травмою. Наслідки не пережитого горя ми вже описували.

Аналіз статистичної значущості відмінностей двох середніх значень для обох груп на етапі другого тестування для незалежних виборок показав, що відмінності виявлені на рівні статистичної тенденції. Значення t-крітерія шкалі адаптивні копінг-стратегії відрізняються. В нашому дослідженні при статистично значущих відмінностях $p=0,027(\leq 0,05)$ в рівні вираженості адаптивності до і після проходження програми, значення $\mathbf{t}-$ критерію $=$ $-5,972$, можна говорити про статистично значне зростання значень після проведення програми; тобто проведена програма виявилася ефективною.

При аналізі адаптивних стратегій для контрольної групи статистично достовірні відмінності не виявлено $p=0,116(>0,1)$, значення t-критерію $=-2,675$, що свідчить про незначне зростання значень.

При проведенні порівняння показників тест-ретест даних ЕГ отримані результати в межах статистично значущих відмінностей $p=0,03(\leq 0,05)$ складали по t-критерію $=17,46$, a данні КГ при $p=0,02$ складали по tкритерію $=6,889$.

При аналізі відносно адаптивних стратегій статистично достовірні відмінності не виявлені. В ЕГ при $p=0,271$ t-критерію = - 1,507, а в КГ при $p=0,201$ t-критерію = - 1,881 , тобто зміни незначні. 
Отримані результати дають можливість зробити висновок, що необхідність приймати рішення безпосередньо після втрати стимулює більш пасивні та не адаптивні стратегії.

Оскільки психологічне подолання запускається виникненням певної ситуації, то при втрачанні суб'єктивної значущості цієї ситуації або зпливом часу можна припустити закінчення стратегії подолання. Критерієм успішного подолання $\epsilon$ покращення рівня загального психофізіологічного стану та послаблення почуття враженості.

Тривалість та ефективність процесу подолання може мінятися на різних етапах переживання втрати, що є цілком природним. Але наше дослідження наглядно продемонструвало, що при наданні психологічної допомоги вдовам стають притаманні більш адаптивні копінг-статегії.

\section{Перелік використаних джерел:}

1. Анщыцферова Л. И. Личность в трудных жизненных условиях: переосмысливание, преобразование ситуаций и психологическая защита // Психологический журнал. 1994. T. 15, № 1. C. 3-18.

2. Аргайл М. Психология счастья. — 2-е изд. - СПб.: Питер, 2003. - 271 с: ил. - (Серия «Мастера психологии»).

3. Бодрийяр Жан. Симулякры и Симуляция режим доступуһttp://lit.lib.ru/k/kachalow_a/ simulacres_et_simulation.shtml

4. Бодров B. A. Проблема преодоления стресса. Ч. 3. Стратегии и стили преодоления стресса // Психологический журнал, 2006. Т. 27, № 3. С. 106-116

5. Волков А. М., Микадзе Ю. В., Солнцева Г. Н., Дея- тельность: структура и регуляция.М., 1987.

6. Горностай П. П., Проблемний аналіз в консультативній практиці, Практична психологія: теорія, методи, технології: Матеріали наук. семінару.- К.: НікаЦентр, 1997.- С. 72-78., режим доступуhttp:/gorn.kiev.ua/ publ02.htm

7. Зоткин Н. В., Психологическая концепция смысла, http://scorcher.ru/art/life/art/7.htm

8. Ильин Е. П. Эмоции и чувства. - СПб: Питер, 2001. - 752 с: ил. - (Серия «Мастера психологии»).

9. Косолапов Н. А., Глоссарий по политической психологии.Авторский коллектив РУДН, с.106

10. Либин A. В., Стили реагирования на стресс: психологическая защита или совладание со сложными обстоятельствами?/Стиль человека: психологический анализ / Под ред. А.В. Либина. Москва: Смысл, 1998. - 310 c.

11. Мечников И. И. Этюды оптимизмаМ.: Наука, Главная редакция литературы на ин. яз., 1988. - 328 с

12. Посохова C. T. Оптимизм: психологическое содержаниеи личностный смысл/Вестник СанктПетербургского Университета Сер. 12. 2009. Вып. 1. Ч. I, c.5-16, c. 11

13. Рибик Л. А. Вторинний посттравматичний стресовий розлад у дружин учасників бойових дій//Юридична психологія. 2016. № 2 (19)

14. Словник української мови: в 11 томах. - Том 8, 1977. - Стор. 313.

15. Словник української мови: в 11 томах. - Том 9, 1978. - Стор. 404.

16. Трофимова И. Стилевые характеристики и параметры стратегий поведения. / Стиль человека: психологический анализ / Под ред. А.В. Либина. Москва: Смысл, 1998. - 310 c., с. 81

17. Трубецүкой Е. Н. Смысл жизни.. , М.: Республика, 1994. - 432: - (Мыслители XX века), С.5

18. Ялтонский В. М., Сирота Н. А. Психология совладающего поведения: от века двадцатого в век двадцать первый (развитие, достижения, проблемы, перспективы) режим доступуhttp:/clinical-psy.ru/wp-content/ 
uploads/KLINICHESKAYA-PSIHOLOGIYASOVLADAYUSHHEGO-POVEDENI1.pdf

19. Leventha $H$. The integration of emotion and cognition: A view from perceptual-motor theory of emotion, -in: M.S. Clark\&S. T. Fiske (Eds.). Affect and cognition. -Hillsdale, NJ,Erl- baum, 1982,121-156.

20. Mayers D. Big Ideas in Social Psychology and Religion //www.davidmyers.org

21. Neal A. National trauma and collective memory. Majore vents in the American century. N. - Y., 1998

22. Stroebe M. S., Schut H. 1999. The dual process model of coping with bereavement: rationale and description. DeathStud.23:197 224

\section{References (Transsliteration):}

1. Antsyiferova L. I. Lichnost v trudnyih zhiznennyih usloviyah: pereosmyislivanie, preobrazovanie situatsiy i psihologicheskaya zaschita // Psihologicheskiy zhurnal. 1994. T. 15, \# 1. S. 3-18.

2. Argayl M. Psihologiya schastya. — 2-e izd. - SPb.: Piter, 2003. — 271 s: il. — (Seriya «Mastera psihologii»).

3. Bodriyyar Zhan. Simulyakryi i Simulyatsiya rezhim dostupuhttp://lit.lib.ru/k/kachalow_a/

simulacres_et_simulation.shtml

4. Bodrov V. A. Problema preodoleniya stressa. Ch. 3. Strategii i stili preodoleniya stressa // Psihologicheskiy zhurnal, 2006. T. 27, \# 3. S. 106-116

5. Volkov A. M., Mikadze Yu. V., Solntseva G. N., Deyatelnost: struktura i regulyatsiya.M., 1987.

6. Gornostay P. P., Problemniy analIz v konsultativnIy praktitsI, Praktichna psihologIya: teorIya, metodi, tehnologIYi: MaterIali nauk. semInaru.- K.: NIkaTsentr, 1997.- S. 72-78., rezhim dostupuhttp://gorn.kiev.ua/publ02.htm

7. Zotkin N. V., Psihologicheskaya kontseptsiya smyisla, http://scorcher.ru/art/life/art/7.htm

8. Ilin E. P. Emotsii i chuvstva. — SPb: Piter, 2001. - 752 s: il. — (Seriya «Mastera psihologii»).

9. Kosolapov N. A., Glossariy po politicheskoy psihologii.Avtorskiy kollektiv RUDN, s.106
10. Libin A. $V$., Stili reagirovaniya na stress: psihologicheskaya zaschita ili sovladanie so slozhnyimi obstoyatelstvami?/Stil cheloveka: psihologicheskiy analiz / Pod red. A.V. Libina. Moskva: Smyisl, 1998. - 310 s.

11. Mechnikov I. I. Etyudyi optimizmaM.: Nauka, Glavnaya redaktsiya literaturyi na in. yaz., 1988. - $328 \mathrm{~s}$

12. Posohova S. T. Optimizm: psihologicheskoe soderzhaniei lichnostnyiy smyisl/Vestnik Sankt-Peterburgskogo Universiteta Ser. 12. 2009. Vyip. 1. Ch. I, s.5-16, s.11

13. Ribik L. A. Vtorinniy posttravmatichniy stresoviy rozlad u druzhin uchasnikIv boyovih dIy//Yuridichna psihologIya. 2016. \# 2 (19)

14. Slovnik ukrayinskoyi movi: v 11 tomah. - Tom 8, 1977. - Stor. 313.

15. Slovnik ukrayinskoyi movi: v 11 tomah. - Tom 9, 1978. — Stor. 404.

16. Trofimova I. Stilevyie harakteristiki i parametryi strategiy povedeniya. / Stil cheloveka: psihologicheskiy analiz / Pod red. A.V. Libina. Moskva: Smyis1, 1998. - 310 s., s. 81 17. Trubetskoy E. N. Smyisl zhizni.., M.: Respublika, 1994. — 432: - (Myisliteli XX veka), S.5

18. Yaltonskiy V. M., Sirota N. A. Psihologiya covladayuschego povedeniya: ot veka dvadtsatogo $\mathrm{V}$ vek dvadtsat pervyiy (razvitie, dostizheniya, problemyi, perspektivyi) rezhim dostupuhttp://clinical-psy.ru/wp-content/ uploads/KLINICHESKAYA-PSIHOLOGIYA-

\section{SOVLADAYUSHHEGO-POVEDENI1.pdf}

19. Leventha $H$. The integration of emotion and cognition:

A view from perceptual-motor theory of emotion, -in: M.S.

Clark\&S. T. Fiske (Eds.). Affect and cognition. -Hillsdale, NJ,Erl- baum, 1982,121-156.

20. Mayers D. Big Ideas in Social Psychology and Religion //www.davidmyers.org

21. Neal A. National trauma and collective memory. Majore vents in the American century. N. -Y., 1998.

22. Stroebe M. S., Schut H. 1999. The dual process model of coping with bereavement: rationale and description. DeathStud.23:197 224 


\section{Rybyk Larisa}

PhD, National Academy of Internal Affairs, Kyiv (Ukraine)

\section{RESEARCH OF COPING STRATEGIES OF LOSS OVERCOMING IN SYSTEMIC PSY- CHOLOGICAL SUPPORT OF POLICE OF- FICER'S WIDOWS}

\section{ABSTRACT}

The subjective choice of coping strategies when experiencing loss is based on the individual psychological peculiarities and experience of overcoming difficult life situations. However, any experience of an extreme situation can be divided into three varieties - problem-oriented, emotionally-oriented and avoidance. The basic behavioral patterns of overcoming can also be characterized as instrumental - focused on specific actions and palliative - aimed at emotional reactions regulation.

In the situation of loss, no action can solve the problem of the death of a loved one, and control, regulation or suppression of emotions can lead to negative consequences, such as depression or psychosomatic illness. In this context, coping strategies are considered as a synthesis of adequate experience of loss and adaptation to a changed system of life. This is consistent with the concept of a double process of overcoming behavior - a response to stress and, directly, anxiety.

The choice of coping strategy complies to the desire for optimal interaction of the individual with his life circumstances and at the same time, the structural and functional organization of the psyche is unchanged, regardless of the type of activity.

Key components of the structure of coping strategies - information, activity, resource. Formation of psychological overcoming occurs under the influence of stable determinants integrating the crisis through the prism of individuality.

Factors that influence the choice of doping strategy are the structure of the individual, objective living conditions, resources, internality / externality, the implementation of short-term or long-term plans.

Personality activities are aimed at creating of the comfortable living environment that activates existing patterns of behavior or creating of a new response paradigm. Formation and timely controlled use of sustainable and situational determinants is foreseen for successful adaptation in the changing conditions of existence,

The analysis of widow's coping strategies, inclusive of the situation of loss, has caused a controversial perception of the adaptability / non-adaptability of individual strategies. Adaptive strategies - preserving self-esteem can lead to suppression of feelings and nervous breakdown, and while working through grief, the main thing are open emotional experience. Nonadaptive strategies - ignoring, as a kind of apathy behavior for resources saving; humility, a necessary factor for the death acceptance, that is, to accept fate. Relatively adaptive strategies - emotional discharge, as a reboot of the body; compen- 
sation and distraction help to survive the grief.

The results of the research indicate a positive effect of psychological support on the person's adaptability, namely, in the cognitive sphere, the indicators on the scale of 'confusion' and 'ignoring' are decreasing; in the emotional sphere, the strategies of 'suppressing emotions' and 'self-excuse' were less used; in the behavioral sphere indicators of 'active avoidance' decreased, but the strategy of 'constructive activity' began to be used more often.

A comparative analysis of the indicators of the group that participated in the psychological support experiment and the control group gives grounds to conclude that women who decide to manage their loss in dependently, avoid to contact with the trauma primarily, while women who received psychological help, suffer a loss in a more adaptive way.

Key words: widows, coping strategies, psychological trauma, personality adaptation.

\section{Рыбык Лариса Анатольевна}

Адъюнкт Национальной академии внутренних дел, г. Киев (Украина)

\section{ИССЛЕДОВАНИЕ ПРИСУЩИХ ЖЕНАМ ПОГИБШИХ ПРАВООХРАНИТЕЛЕЙ КОПИНГ-СТРАТЕГИЙ ПЕРЕЖИВАНИЯ ПОТЕРИ ПРИ СИСТЕМНОМ ПСИХОЛОГИЧЕСКОМ СОПРОВОЖДЕНИИ}

Аннотация. Субъективный выбор копинг-стратегий при переживании потери основывается на индивидуально-психологической особенности и опыте преодоления трудных жизненных ситуаций. Однако любое переживание экстремальной ситуации можно разделить на три вида - проблемноориентированное, эмоциональноориентированное и избегание. Основные модели поведения преодоления можно характеризовать как инструментальные - направленные на конкретные действия и паллиативные направленные на управление эмоциональными реакциями.

В ситуации потери никакими действиями нельзя решить проблему смерти близкого человека, а контроль, управление или подавление эмоций может привести к негативным последствиям, таким как депрессия или психосоматические заболевания. В этом контексте копинг-стратегии рассматриваются как синтез адекватного переживания потери и адаптации к измененной системы жизнедеятельности. Это соответствует концепции двойного процесса совладающего поведения - peакция на стресс и, непосредственно, переживания.

Выбор копинг-стратегии подчиняется желанию оптимального взаимодействия личности с ее жизненными обстоятельствами, но в тоже время структурно-функциональная организация психики неизменна, независимо от вида деятельности.

Ключевые составляющие структуры копинг-стратегий - информация, деятельность, ресурснисть. Формирование психологического преодоления происходит под влияни- 
ем устойчивых детерминант интегрируя кризис через призму индивидуальности.

Факторы, влияющие на выбор копингстратегии - структура личности, объективные условия жизнедеятельности, ресурсы, интернальность / экстернальность, реализация краткосрочных или долгосрочных планов.

Деятельность личности направлена на создание комфортной среды обитания, активирует имеющиеся модели поведения или создания новой парадигмы реагирования. Для успешной адаптации в меняющихся условиях существования предусматривается формирование и своевременное контролируемое использование устойчивых детерминант и ситуативных.

Анализ характерных вдовам копингстратегий с учетом ситуации потери вызвал дискуссионный восприятия адаптивности / неадаптивности отдельных стратегий. Адаптивные стратегии - сохранение самообладание может привести к подавлению чувств и истощения нервной системы, а в работе горя главное - открытое проживания эмоций. Неадаптивные стратегии - игнорирование, как вид апатичной поведения, для сохранения ресурса; смирение, обязательное условие принятия смерти, то есть смириться с судьбой. Относительно адаптивные стратегии - эмоциональная разрядка, как перезагрузка организма; компенсация и отвлечения помогают пережить печаль.

Результаты исследования свидетель- ствуют о положительном влиянии психологического сопровождения на адаптивность личности, а именно в когнитивной сфере уменьшаются показатели по шкале «растерянность» и «игнорирование»; в эмоциональной сфере меньше применялись стратегии «подавление эмоций» и «самообвинения»; в поведенческой снизились показатели «активного избегания», но чаще стала применяться стратегия «конструктивная активность».

Сравнительный анализ показателей группы, принимавшей участие в эксперименте психологического сопровождения и контрольной группы дает основания сделать вывод, что женщины которые решили самостоятельно справляться с потерей, прежде всего избегают сталкиваться с травмой, в то время как женщины, которые получили психологическую помощь переживают потерю более адаптивным способом.

Ключевые слова: вдовы, копингстратегии, психологическая травма, адаптация личности.

Дата отримання статті: 9.04.2018 Дата рекомендації до друку: 17.04.2018 Дата оприлюднення: 19.04.2018 